\title{
SPOZNAJ SEBE IN DRUGE: človek kot družbeno bitje in medosebni odnosi
}

\author{
Ljubljana, Društvo za izobraževanje za tretje življenjsko \\ obdobje, 2014
}

Raziskovanje, razvoj novega študijskega programa in 12 let vodenja študijskih skupin transakcijske analize na Slovenski univerzi za tretje življenjsko obdobje dajejo verodostojen okvir predstavljenim teorijam in posplošenim spoznanjem v delu prof. dr. Ane Krajnc, knjigi s preprostim, a zgovornim naslovom Spoznaj sebe in druge. Avtorica se v uvodu zahvali starejšim študentkam in študentom, ki so jo s svojim zanimanjem, vprašanji in primeri vodili v obravnavo tem, ki so postale središče tega dela.

Knjiga je pisana za širši krog bralcev in namenoma ni ozko znanstvena, kajti kot pravi Eric Berne, »si teorija zasluži širšo prakso«. Otrese naj se psihopatologije, obravnave zgolj kliničnih primerov, in se poda med običajne ljudi. Pomaga naj jim razumeti in boljšati odnose sredi vsakdanjega življenja. Prav takšen je bil tudi avtoričin namen.

Avtorica uvodoma poudari, da se človek razvija vse življenje in da v razvoju nikakor ne more obstati na isti točki. Tako bodisi napreduje (progresija) ali nazaduje (regresija). Če napreduje, razvije nove oblike čustvovanja, vedenja, pridobiva nove sposobnosti pa tudi stališča in veščine. Regresija pa ga povleče v nekdanje, najpogosteje neprimerne in mučne oblike čustvovanja in vedenja. Če so bile te v otroštvu potrebne, v odraslosti niso najustreznejše. Osebnostni razvoj (progresija) okrepi kompetentnost, neodvisnost, odkrivanje, doživljanje in s tem spoštovanje samega sebe, s tem pa je ustvarjena podlaga za samouresničenje (odkrivanje sebe, kakršen človek postane), kar je pomemben predmet obravnave v tem delu. Možnosti za uresničenje samega sebe, za spreminjanje samega sebe in za potrjevanje, ki prihaja od drugih, te možnosti nam daje ali odvzame okolje.

Avtorica obravnava psihodinamiko odnosov in ponovi prepričanje, da se človek zmeraj, v vsakem trenutku, obnaša na najboljši možni način, kot ga pač takrat zmore. Pri tem na svet lahko gleda negativno ali pozitivno, pa ne tako, da si pred ogledalom ponavlja, kako krasen in najboljši je (dresura pozitivnega mišljenja), marveč je njegov pogled na svet lahko pozitiven le, če je na svoji življenjski poti doživel tisoče nagrajujočih trenutkov. V izobraževanju iz transakcijske analize je mogoče transformacijo pogleda in doživljanja doseči s transformativnim učenjem, ki se tam sproži, ko študent 
s pomočjo izobraževanja dobi uvid vase, druge in situacije, ko doživi, da je sprejet in da ga drugi razumejo in mu dajejo potrditev.

Avtorica se posebej posveti družbeni naravi človeka. Odnos z drugimi je temelj človečnosti. Tako tudi naše vedênje ne izvira le iz nas samih. Človek je družbeno in odnosno bitje in v odnosu do nekoga je lahko zelo drugačen, kot je v odnosu do drugega; v odnosu z mnogimi, še posebej zanj pomembnimi odraslimi se je tudi oblikoval.

Pomembna tema so primarne psihosocialne potrebe. Primarne zato, ker se z njimi rodimo prav vsi, psihosocialne zato, ker jih lahko zadovoljujemo le skupaj z drugimi. Ana Krajnc zastane ob vprašanju permisivne in represivne vzgoje ter njunega vpliva na razvoj človeka, a načne tudi vprašanje, kako se v medsebojnih odnosih branimo. Medsebojna uporaba je vez med ljudmi in nič ni narobe, če se navežemo drug na drugega prav zato, ker si medsebojno zadovoljujemo potrebe. Odnos je vsekakor izmenično dajanje in prejemanje in je vez z drugimi. Ni pa prav in čustveno je izčrpavajoče - pa se tega morda niti ne zavedamo -, če smo v odnosu zlorabe. Prav je, da to prepoznamo in ukrepamo, četudi se zdi včasih težko, še posebno, če smo se ujeli v mreže manipulatorjev in njihovih manipulacij ne prepoznamo, čutimo pa, da nam zmanjkuje moči.

Pomembno poglavje tega dela so še samopodoba in obrambni mehanizmi, denimo agresivnost, pasivnost in umik, zanikanje, sanjarjenje, laž, projekcija. To so nezavedni duševni procesi, ker ne vemo, da se dogajajo, a njihovo posledično vedenje zaznamo. Sprožajo se, da olajšajo doživljanje nelagodnih čustev, da uravnavajo čustva, da nam omogočajo prilagajanje na situacije in spremembe.

Prav posebno vrednost tega dela vidimo bralci v tem, da je avtorica zbrala in osvetlila razumevanje vrste avtentičnih primerov, primerov iz našega kulturnega okolja. To nemalokrat ni preprosto, kajti za razumevanje psihičnih mehanizmov, ki delujejo v sedanjosti, si moramo zaupati zgodbe in primere iz življenja in preteklosti, odkrivati prožne vezi, ki iznenada povežejo pretekle situacije z današnjimi. Takrat se sprožijo davna, že pozabljena čustva in občutki, ki vplivajo na vedênje, odnose in komunikacijo, čustva, proti katerim se branimo, branimo vsak na svoj način z obrambnimi mehanizmi, brez katerih bi bili bosi in ranljivi. Zato je dobro, da jih imamo in jih uporabljamo, četudi se včasih izkažejo za neprimerne in boleče za nas in za druge.

Delo bo mnogim dalo odgovor na zapletena vprašanja, ki obvladujejo njihovo življenje, včasih do take mere, da ne razumejo, kaj in zakaj se jim dogaja.

Dušana Findeisen 
Rutar Ilc, Zora; Tacer, Blanka in Žarkovič Adlešǐ̌, Brigita:

\title{
KOLEGIALNI COACHING: PRIROČNIK ZA STROKOVNI IN OSEBNI RAZVOJ
}

\author{
Ljubljana, Zavod RS za šolstvo, 2014
}

Kolegialni coaching avtoric Zore Rutar Ilc, Blanke Tacer in Brigite Žarkovič Adlešič je prvi priročnik za to področje, ki je plod slovenskega znanja. Na eni strani je sistematičen, metodičen, do bralca prijazno zasnovan, didaktično bogat in strokoven vodnik po osnovah coachinga; na drugi strani temelji na praktičnih primerih, v katerih skozi refleksijo uporabnikov in preizkuševalcev coachinga bralcu omogoča neposreden vpogled $\mathrm{v}$ njihovo učenje, napredek in razvoj. Pri tem ponuja nekatere preproste tehnike, orodja in modele ter bralcu na slikovit način pokaže, kako jih uporabiti v praksi. Primere uporabe začini še z izkušnjami in refleksijo tistih, ki so to že storili.

Avtorice ostajajo pri izrazu coaching, ki se je kljub več (neuspešnim) poskusom slovenjenja »prijel« in ga v strokovni javnosti jasno razlikujemo od sorodnih pojmov, med temi so največkrat trenerstvo oziroma usposabljanje, svetovanje, mentorstvo, pa tudi (psiho)terapija. V slovenskem prostoru smo pogosto usmerjeni z naučeno nemočjo, zato je kolegialni coaching možnost (in tudi odgovornost vseh, ki so se udeležili osnovnega usposabljanja), da s pozitivnim in na opolnomočenju temelječim pristopom gradijo prakso in ga zavestno uporabljajo v različnih okoljih. Kolegialni coaching, ki je proces med dvema kolegoma, slednjima omogoča (vzajemno) podporo in doseganje želenih ciljev, s tem pa tudi strokovni in osebni razvoj. Temelji namreč na virih vsakega posameznika in ga poziva, da zamenja drže ne znam, ne da se s pristopom, ki ga označujejo vprašanja kaj hočem, kaj je odvisno od mene, katere so moje kompetence in kaj je moj prvi korak.

Coaching, kot je predstavljen v priročniku, izhaja iz nevrolingvističnega programiranja in praktičnih obravnav avtoric, ki so obogatene s konkretnimi izzivi uporabnikov ter primeri napačnega, neustreznega (največkrat naučenega negativnega) pristopa ter ustreznejšega - coaching pristopa. Drugače povedano: če osnovni izziv temelji na problemskem okviru in izhaja iz neprijetnih čustev ter »ciklanja «v lastni nemoči, avtorice pokažejo, kako je s coaching pristopom mogoče preseči problemski okvir ter kolega ciljno usmeriti k rešitvam tako, da opredeli svoj cilj, vire za njegovo doseganje, morebitne omejitve (med njimi pogosto omejujoča prepričanja), koristi, ki jih bo rešitev oziroma doseganje cilja prineslo, ter korake, ki so za to potrebni. 
Knjiga je razdeljena na šest poglavij, ki se med seboj nadgrajujejo in dopolnjujejo. Prvi del opredeli coaching in kolegialni coaching, v drugem delu so sistematično predstavljene nekatere veščine, v tretjem in četrtem modeli in orodja coachinga. Peti del se ukvarja s psihološkimi osnovami coachinga, šesti del predstavi izkušnje pri uporabi kolegialnega coachinga, med njimi tudi načine njegove sistemske vpeljave v šolski prostor.

Bistvo coachinga so spremembe prepričanj, identitete in osebnostni razvoj. To od coacha zahteva ustrezna orodja, metode in tehnike ter številna druga znanja, ki so plod dolgoletnega študija, usposabljanja in poglobljenega dela na sebi. Ambicija priročnika Kolegialni coaching ni, da bi segel tako daleč, čeprav predstavi nekatera diagnostična orodja tudi za delo s temi strukturami.

Čeprav Kolegialni coaching izhaja iz šolskega prostora in je prvenstveno namenjen učiteljem ter drugim šolskim delavcem, je dobrodošel priročnik za vse, ki se profesionalno ukvarjajo s coachingom ne glede na področje delovanja, in tudi za tiste, ki se s coachingom šele seznanjajo. Nikakor pa ni nadomestek za temeljito (vsaj 100-urno) usposabljanje iz coachinga. Coaching je pač več kot samo veščina in obrt. Od coacha se pričakujeta pozitivna naravnanost in visoka etična notranja drža. Usposabljanje coacha preizprašuje posameznikova prepričanja, vedenja, strategije in tudi njegovo poslanstvo, zato se coachinga ni mogoče (na)učiti le iz knjig. Knjige in različni priročniki so stalni spremljevalci na coachevi strokovni poti. Le coach, ki sam nenehno raste in se samoizprašuje, lahko pomaga pri osebni in profesionalni rasti tudi drugim. Verjamem, da je na tej poti osebne in strokovne rasti coachu lahko dober sopotnik tudi priročnik Kolegialni coaching.

Karin Elena Sánchez. 